E. В. Лаврентьева, В. С. Раднаев. Поиск природных пептидаз в микробном мате горячего источника Гарга и их разнообразие

УДК 579.262(282.256.3)

DOI 10.18101/2306-2363-2020-1-45-53

\title{
ПОИСК ПРИРОДНЫХ ПЕПТИДАЗ В МИКРОБНОМ МАТЕ ГОРЯЧЕГО ИСТОЧНИКА ГАРГА И ИХ РАЗНООБРАЗИЕ
}

\author{
(C) Лаврентьева Е. В. \\ кандидат биологических наук, \\ Институт общей и экспериментальной биологии СО РАН \\ Россия, 670047, г. Улан-Удэ, ул. Сахьяновой, 6 \\ Бурятский государственный университет имени Доржи Банзарова \\ Россия, 670000, г. Улан-Удэ, ул. Смолина, 24a \\ E-mail: lena_1@mail.ru \\ (C) Раднаев В. C. \\ Бактериологическая лаборатория \\ Больница скорой медицинской помощи им. В. В. Ангапова \\ Россия, 670000, г. Улан-Удэ, ул. Профсоюзная, 48а
}

\begin{abstract}
Цель исследования - определить природные пептидазы в микробном мате горячего источника Гарга и их разнообразие. Статья посвящена комплексному исследованию пептидаз, которые представляют отдельную группу гидролитических ферментов участвующие в разложение органического вещества. Научная новизна работы заключается в анализе препаратов микробных сообществ горячих источников Байкальской рифтовой зоны методом высокопроизводительного секвенирования, которые обеспечивают гидролиз биополимеров на первых этапах деструкции органического вещества. В результате был проведен метагеномный анализ, который позволил выявить распространение пептидаз класса металлопептидаз в изученных микробных сообществах. В метагеномных последовательностях были идентифицированы потенциальные пептидазы, которые могут представлять биотехнологический интерес.
\end{abstract}

Ключевые слова: пептидазы; микробный мат; гидролитические ферменты; металлопептидазы; метагеномомы; секвенирование; Байкальская рифтовая зона.

Для цитирования: Лаврентьева E. B., Раднаев B. C. Поиск природных пептидаз в микробном мате горячего источника Гарга и их разнообразие // Вестник Бурятского государственного университета. Химия. Физика. 2020. Вып. 1. С. 45-53.

Гидролитические бактерии являются инициаторами процесса разложения органического вещества в микробных сообществах природных местообитаний. За последнее десятилетие появляется все больше информации о наличии полного комплекса гидролитических ферментов у представителей прокариот [1-3]. Интенсивность их деятельности очень сильно зависит от многих экологических факторов, в том числе температуры, окислительно-восстановительных условий, реакции среды. В составе органического вещества одним из основных компонентов является белок. Процесс протеолиза имеет важное биологическое значение, так как играет регулирующую роль в функционировании как клетки, так и экосистемы в целом.

Пептидазы (ЕС. 3.4) представляют собой отдельную подгруппу гидролитических ферментов, которые катализируют расщепление пептидных связей в белковых субстратах. В зависимости от способа действия и каталитического механиз- 
ма пептидазы делятся на шесть основных классов, включая сериновые пептидазы (ЕС. 3.4.21), цистеиновые пептидазы (ЕС. 3.4.22), аспарагиновые пептидазы (ЕС. 3.4.23), металлопептидазы (ЕС. 3.4.24), треониновые эндопептидазы (3.4.25) и глутаминовые (3.4.23.32) (http://merops.sanger.ac.uk/). В дополнение к их ключевой метаболической и физиологической значимости, они имеют различное коммерческое применение во всем мире.

Процесс деструкции белка пептидазами в природных экосистемах слабоизучен, известно лишь несколько работ, посвященных изучению гидролиза белка в морских экосистемах [2, 4] и в почве [5].

\section{Объекты и методы исследования}

Высокотемпературный источник Гарга находится в долине р. Гарги, расположен в отрогах Икатского хребта, окаймляющего котловину с восточной стороны

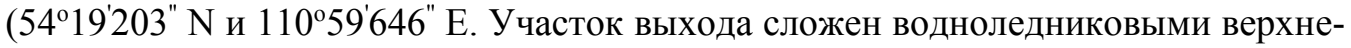
четвертичными отложениями, которые перекрывают палеозойские граниты, и связаны с мощным Гаргинским разломом, протягивающимся в северо-восточном направлении на 30-40 км. Температура воды на изливе достигает $74^{\circ} \mathrm{C}, \mathrm{pH} 8,3$.

Поиск пептидаз в микробном мате горячего источника Гарга проведен в ООО «Биоспарк», г. Москва.

\section{Результаты и обсуждение}

Физико-химические условия горячего источника Гарга

Термальная сульфатно-натриевая вода изливается со скоростью 5 л/с в небольшой грот, расположенный на правом берегу реки Гарга, на высоте около 100 м от уреза воды (674 м над уровнем моря). Температура воды на выходе достигает $74^{\circ} \mathrm{C}$. Вода, стекая по ручью, образует травертин высотой 1,5-2 м, длиной до 50 м, шириной до 25 м и является одним из самых крупных в Байкальском регионе.

Химический состав воды (табл. 1). Доминирующий катион - $\mathrm{Na}^{+}$, его содержание составило 312,04 мг/дм ${ }^{3}$. Концентрации ионов $\mathrm{Mg}^{2+}, \mathrm{K}^{+}$и $\mathrm{Ca}^{2+}$ составили $0,08,11,3$ и 23 мг/дм³, соответственно. Содержание карбонатов составило 6 мг/дм ${ }^{3}$, гидрокарбонатов - 109 мг/дм³ ${ }^{3}$ Концентрация сульфатов 390 мг/дм³. Содержание хлоридов и фторидов 51 мг/дм³ и 11 мг/дм³, соответственно. Для источника Гарга характерно высокое содержание радона, до 43 эман.

Таблица 1

Химический состав воды горячего источника Гарга, мг/дм³

(в месте отбора микробного мата)

\begin{tabular}{|c|c|c|c|c|c|c|c|c|c|c|c|c|}
\hline $\mathrm{Na}^{+}$ & $\mathrm{K}^{+}$ & $\mathrm{Ca}^{2+}$ & $\mathrm{Mg}^{2+}$ & $\mathrm{CO}_{3}{ }^{2-}$ & $\mathrm{HCO}_{3}{ }^{-}$ & $\mathrm{NO}_{3}{ }^{-}$ & $\mathrm{NO}^{2-}$ & $\mathrm{SO}_{4}{ }^{2-}$ & $\mathrm{H}_{2} \mathrm{SiO}_{3}$ & $\mathrm{~F}$ & $\mathrm{PO}_{4}{ }^{3-}$ & $\mathrm{Cl}^{-}$ \\
\hline 312,04 & 11,3 & 23 & 0,08 & 6 & 109,83 & 7,4 & 0,004 & 390 & 89 & 10,5 & 2,02 & 51,41 \\
\hline
\end{tabular}

Микроэлементный состав воды показал, что в Гаргинских водах отмечены повышенные концентрации $\mathrm{B}, \mathrm{Rb}, \mathrm{Li}, \mathrm{Ba}, \mathrm{Sr}$. Повышенные содержания данных элементов в целом характерны для термальных источников, разгружающихся в 
E. В. Лаврентьева, В. С. Раднаев. Поиск природных пептидаз в микробном мате горячего источника Гарга и их разнообразие

пределах Икатского хребта. Высокие содержания Sr и некоторых других элементов в горячем источнике связаны с их высоким содержанием в гранитоидных породах Баргузинского комплекса.

Для поиска природных пептидаз был отобран микробный мат при температуре воды $54,2^{\circ} \mathrm{C}, \mathrm{pH}$ воды составила 8,3 и минерализация 0,74 г/ дм ${ }^{3}$.

\section{Метагеномный анализ}

На первой стадии выполнения работ по метагеномному анализа были получены данные по поглощению света препаратом ДНК (рис. 1, табл. 2)

Таблица 2

Качество и количество ДНК в полученных препаратах (Гарга)

\begin{tabular}{|c|c|c|c|c|c|c|c|c|}
\hline $\begin{array}{c}\text { A260 } \\
\text { Concent- } \\
\text { ration } \\
\text { (ng/ul) }\end{array}$ & $\begin{array}{l}\text { A230 } \\
(10 \\
\mathrm{mm})\end{array}$ & $\begin{array}{l}\text { A260 } \\
(10 \\
\mathrm{mm})\end{array}$ & $\begin{array}{l}\text { A280 } \\
(10 \\
\mathrm{mm})\end{array}$ & $\begin{array}{c}\text { Raw } \\
\text { A340 } \\
(10 \\
\text { mm })\end{array}$ & $\begin{array}{c}\mathrm{A} 260 \\
/ \mathrm{A} 23 \\
0\end{array}$ & $\begin{array}{c}\mathrm{A} 260 \\
/ \mathrm{A} 28 \\
0\end{array}$ & $\begin{array}{c}\text { A260 } \\
\text { Turbidi } \\
\text { ty }(10 \\
\text { mm })\end{array}$ & $\begin{array}{l}\text { Общее } \\
\text { кол-во } \\
\text { ДНК, мкг }\end{array}$ \\
\hline 215,94 & 3,24 & 4,32 & 2,22 & 0,9 & 1,33 & 1,94 & 2,23 & 21,6 \\
\hline
\end{tabular}

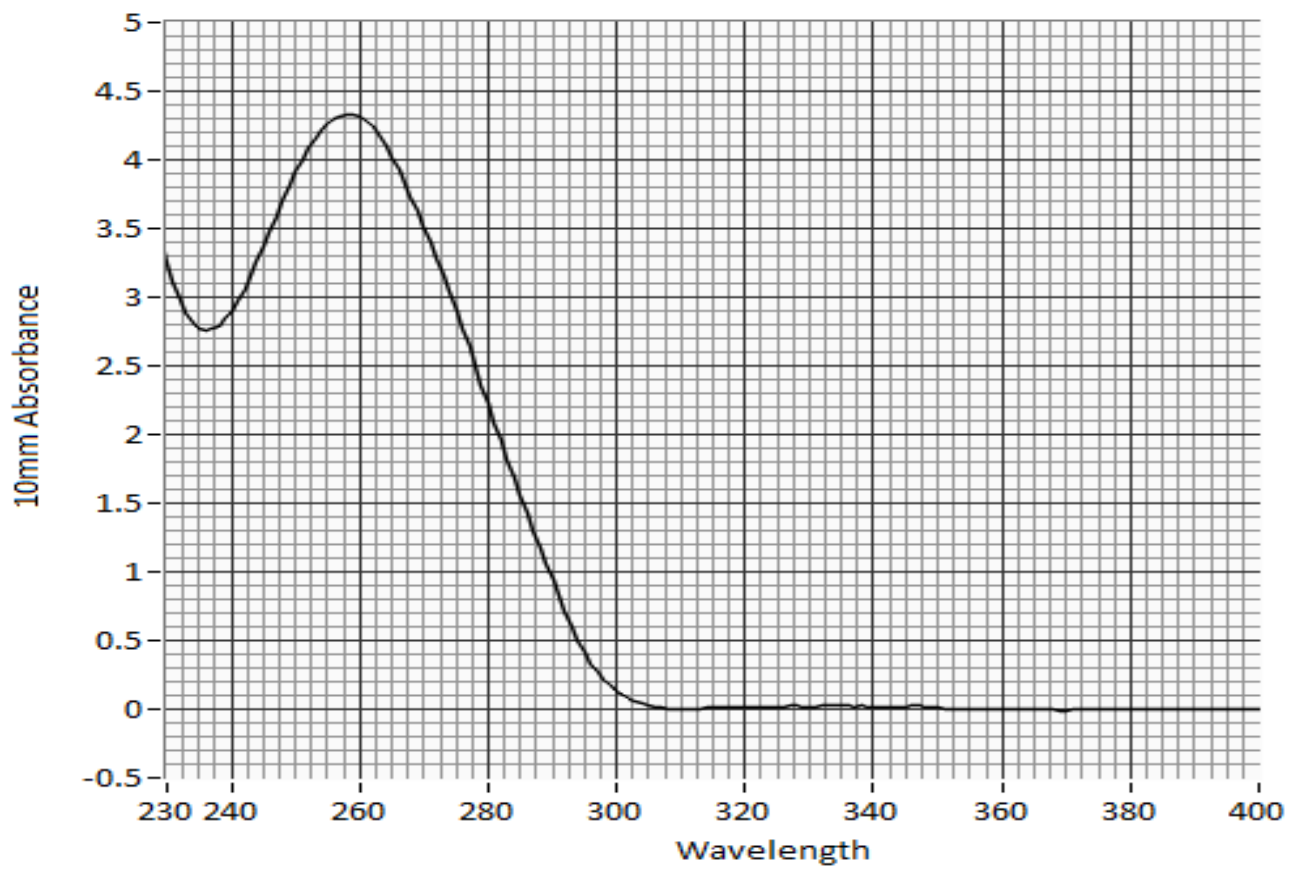

Рис. 1. Кривая поглощения света препаратами ДНК 


\section{Секвенирование полученных библиотек на платформе Illumina HiSeq}

Качественные и количественные характеристики полученных данных секвенирования (табл. 3) Усредненные показатели качества прочтения (Q) каждого нуклеотида (рис. 2).

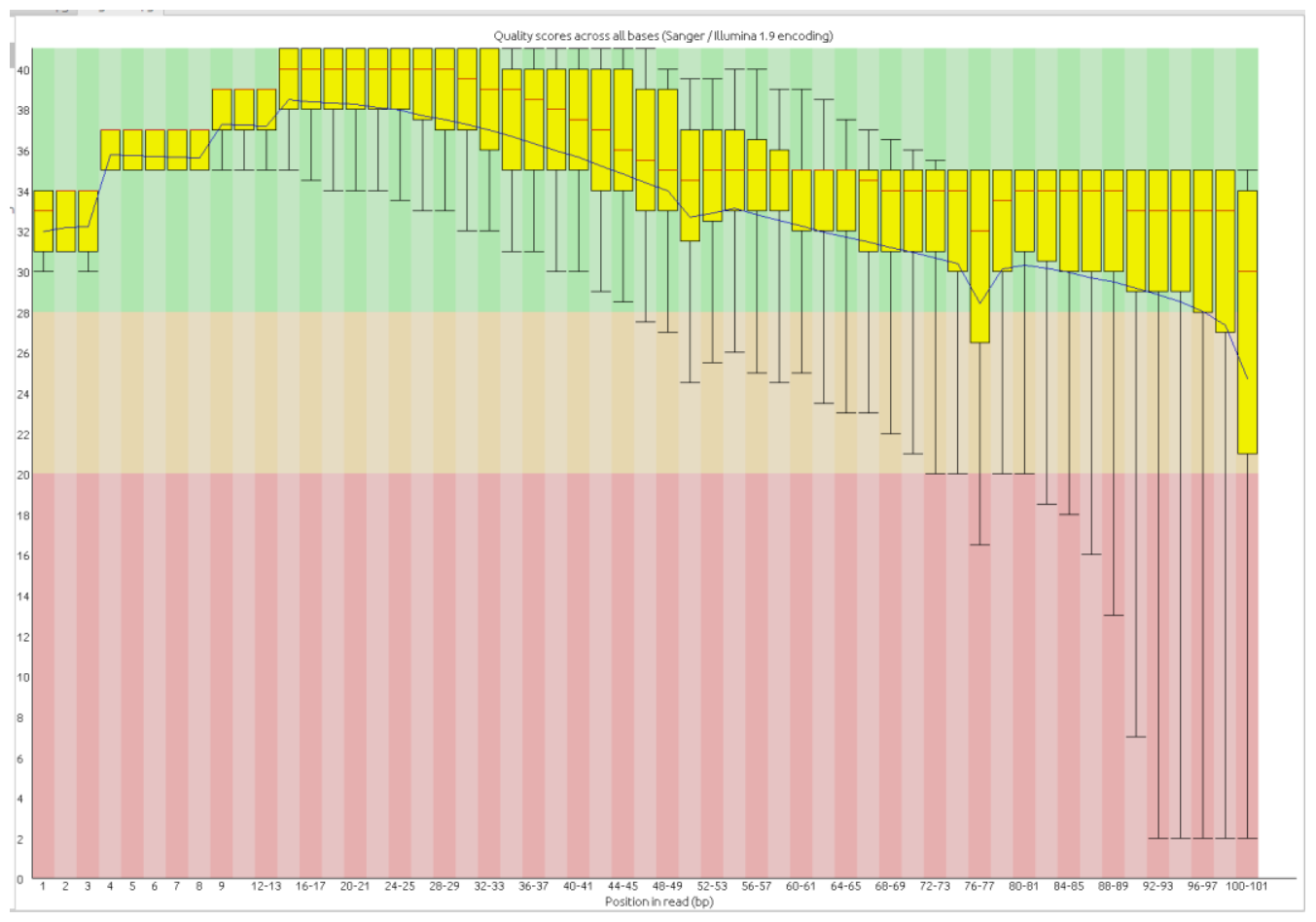

Рис. 2. Усредненные показатели качества прочтения (Q - ось ординат) каждого нуклеотида (позиции обозначены по оси абсцисс)

Таблица 3

Качественные и количественные характеристики полученных данных секвенирования

\begin{tabular}{|c|c|c|c|}
\hline Образец & $\begin{array}{c}\text { Количество } \\
\text { прочтений }\end{array}$ & Длина прочтений & $\begin{array}{c}\text { Усредненный GC состав } \\
\text { прочтений }\end{array}$ \\
\hline Гарга & 94242298 & 101 & $59 \%$ \\
\hline
\end{tabular}

На основании полученной аннотации в изученном образце был получен перечень всех выявленных типов протеаз (табл. 4) 
E. В. Лаврентьева, В. С. Раднаев. Поиск природных пептидаз в микробном мате горячего источника Гарга и их разнообразие

\section{Ферменты, идентифицированные в метагеномных последовательностях, которые могут представлять интерес для биотехнологии}

Таблица 4

Перечень всех выявленных типов протеаз для каждого образца (Гарга)

\begin{tabular}{|c|c|c|}
\hline Тип протеазы & $\begin{array}{c}\text { Код } \\
\text { фермента } \\
\text { по ЕС } \\
\end{array}$ & Номенклатура \\
\hline ATP-dependent Clp protease & 3.4 .21 .92 & $\begin{array}{l}\text { Сериновая пептидаза } \\
\text { Гидролиз белка на мелкие пептиды в } \\
\text { присутствии АТФ и } \mathrm{Mg}^{2+}\end{array}$ \\
\hline $\begin{array}{l}\text { ATP-dependent zinc } \\
\text { metalloprotease }\end{array}$ & 3.4.24.- & Металлоэндопептидаза \\
\hline \multicolumn{3}{|l|}{$\begin{array}{l}\text { CAAX amino terminal protease } \\
\text { self- immunity }\end{array}$} \\
\hline $\begin{array}{l}\text { Carboxy-terminal processing } \\
\text { protease }\end{array}$ & 3.4 .21 .102 & Сериновая пептидаза \\
\hline \multicolumn{3}{|l|}{ Caudovirus prohead protease } \\
\hline Cysteine protease StiP & 3.4.22.- & Цистеиновая эндопептидаза \\
\hline \multicolumn{3}{|l|}{$\begin{array}{l}\text { DNA-binding ATP-dependent } \\
\text { protease La }\end{array}$} \\
\hline Extracellular basic protease & 3.4.21.- & Сериновая эндопептидаза \\
\hline Extracellular metalloprotease & 3.4.21.- & Сериновая эндопептидаза \\
\hline Extracellular serine protease & 3.4.21.- & Сериновая эндопептидаза \\
\hline Germination protease precursor & 3.4 .24 .78 & $\begin{array}{l}\text { Металлоэндопептидазы } \\
\text { Принадлежит семейству пептидаз } \\
\text { M63 }\end{array}$ \\
\hline \multicolumn{3}{|l|}{ Hydrogenase maturation protease } \\
\hline Intracellular serine protease & $3.4 .21 .-$ & Сериновая эндопептидаза \\
\hline \multicolumn{3}{|l|}{$\begin{array}{l}\text { intramembrane serine protease } \\
\text { GlpG }\end{array}$} \\
\hline Lon protease & 3.4 .21 .53 & $\begin{array}{l}\text { Сериновая эндопептидаза La При- } \\
\text { надлежит семейству S } 16\end{array}$ \\
\hline Metalloprotease LoiP & 3.4.24.- & Металлоэндопептидаза \\
\hline Metalloprotease MmpA & 3.4.24.- & Металлоэндопептидаза \\
\hline Minor extracellular protease Epr & 3.4.21.- & Сериновая эндопептидаза \\
\hline Minor extracellular protease vpr & 3.4.21.- & Сериновая эндопептидаза \\
\hline \multicolumn{3}{|l|}{$\begin{array}{l}\text { Multifunctional acyl-CoA } \\
\text { thioesterase I and protease I and } \\
\text { lysophospholipase L1 }\end{array}$} \\
\hline Neutral metalloprotease & 3.4.24.- & Металлоэндопептидааз \\
\hline Neutral protease B & 3.4.24.- & Металлоэндопептидаза \\
\hline \multicolumn{3}{|l|}{ Papain family cysteine protease } \\
\hline $\begin{array}{l}\text { Periplasmic } \mathrm{pH} \text {-dependent serine } \\
\text { endoprotease DegQ }\end{array}$ & 3.4 .21 .107 & $\begin{array}{l}\text { Сериновая эндопептидаза Принад- } \\
\text { лежит семейству S1B }\end{array}$ \\
\hline $\begin{array}{l}\text { Periplasmic serine endoprotease } \\
\text { DegP }\end{array}$ & 3.4 .21 .107 & $\begin{array}{l}\text { Сериновая эндопептидаза Принад- } \\
\text { лежит семейству S1B }\end{array}$ \\
\hline Prohead core protein protease & & \\
\hline
\end{tabular}


ВЕСТНИК БУРЯТСКОГО ГОСУДАРСТВЕННОГО УНИВЕРСИТЕТА

\begin{tabular}{|c|c|c|}
\hline Protease 1 & 3.4 .21 .50 & $\begin{array}{l}\text { Сериновая эндопептидаза } \\
\text { Lysyl endopeptidase }\end{array}$ \\
\hline Protease 2 & 3.4 .21 .83 & $\begin{array}{l}\text { Сериновая эндопептидаза } \\
\text { Oligopeptidase B }\end{array}$ \\
\hline Protease 3 & 3.4 .24 .55 & Металлоэндопептидаза Pitrilysin \\
\hline Protease 4 & 3.4.21.- & Сериновая эндопептидаза \\
\hline Protease HtpX & 3.4.24.- & Металлоэндопептидаза \\
\hline Protease LasA & 3.4.24.- & Металлоэндопептидаза \\
\hline \multicolumn{3}{|l|}{ Protease PrsW } \\
\hline \multicolumn{3}{|l|}{ Protease TldD } \\
\hline Putative CtpA-like serine protease & 3.4.21.- & Сериновая эндопептидаза \\
\hline \multicolumn{3}{|l|}{ Putative cysteine protease YraA } \\
\hline Putative metalloprotease YpwA & 3.4.24.- & Металлоэндопептидаза \\
\hline \multicolumn{3}{|l|}{$\begin{array}{l}\text { Putative peptide zinc } \\
\text { metalloprotease protein YydH }\end{array}$} \\
\hline \multicolumn{3}{|l|}{ Putative protease $\mathrm{Yde} A$} \\
\hline \multicolumn{3}{|l|}{ Putative protease YhbU } \\
\hline \multicolumn{3}{|l|}{ Putative serine protease HhoA } \\
\hline \multicolumn{3}{|l|}{ Putative serine protease HtrA } \\
\hline $\begin{array}{l}\text { Putative subtilase-type serine } \\
\text { protease precursor }\end{array}$ & 3.4.21.- & Сериновая эндопептидаза \\
\hline \multicolumn{3}{|l|}{$\begin{array}{l}\text { Putative zinc metalloprotease } \\
\text { Rip3 }\end{array}$} \\
\hline Putative zinc protease AlbF & 3.4.24.- & Металлоэндопептидаза \\
\hline \multicolumn{3}{|l|}{ Retroviral aspartyl protease } \\
\hline Rhomboid protease AarA & 3.4 .21 .105 & $\begin{array}{l}\text { Сериновая эндопептидаза Rhomboid } \\
\text { protease }\end{array}$ \\
\hline Rhomboid protease GlpG & 3.4 .21 .105 & $\begin{array}{l}\text { Сериновая эндопептидаза Rhomboid } \\
\text { protease }\end{array}$ \\
\hline Rhomboid protease GluP & 3.4 .21 .105 & $\begin{array}{l}\text { Сериновая эндопептидаза Rhomboid } \\
\text { protease }\end{array}$ \\
\hline Serine endoprotease DegS & 3.4 .21 .107 & $\begin{array}{l}\text { Сериновая эндопептидаза Принад- } \\
\text { лежит семейству S1B }\end{array}$ \\
\hline Serine protease AprX & 3.4.21.- & Сериновая эндопептидаза \\
\hline Serine protease Do-like HtrA & 3.4 .21 .107 & $\begin{array}{l}\text { Сериновая эндопептидаза Принад- } \\
\text { лежит семейству S1B }\end{array}$ \\
\hline Serine protease Do-like HtrB & 3.4 .21 .107 & $\begin{array}{l}\text { Сериновая эндопептидаза Принад- } \\
\text { лежит семейству S1B }\end{array}$ \\
\hline Serine protease HtrA-like protein & 3.4.21.- & Сериновая эндопептидаза \\
\hline Serine protease SplB & 3.4.21.- & Сериновая эндопептидаза \\
\hline \multicolumn{3}{|l|}{$\begin{array}{l}\text { Sporulation-specific protease } \\
\text { YabG }\end{array}$} \\
\hline Tail-specific protease & 3.4 .21 .102 & Сериновая эндопептидаза Re \\
\hline \multicolumn{3}{|l|}{$\begin{array}{l}\text { Thermophilic metalloprotease } \\
\text { (M29) }\end{array}$} \\
\hline Thermostable alkaline protease & 3.4.21.- & Сериновая эндопептидаза \\
\hline \multicolumn{3}{|l|}{$\begin{array}{l}\text { Transglutaminase-activating } \\
\text { metalloprotease }\end{array}$} \\
\hline Zinc metalloprotease Rip1 & 3.4.24.- & Металлоэндопептидаза \\
\hline
\end{tabular}


E. В. Лаврентьева, В. С. Раднаев. Поиск природных пептидаз в микробном мате горячего источника Гарга и их разнообразие

В природных местообитаниях гидролитические бактерии занимают нишу первичных деструкторов, благодаря способности гетеротрофно расти на биополимеpax различной природы. Особенностью изученных микробных сообществ термальных источников Прибайкалья является его термофилия и алкалитолернатность, что предполагает термо- и $\mathrm{pH}$ стабильность соответствующих ферментов.

Проведенный метагеномный анализ позволил выявить гены пептидаз в природном образце микробного мата горячего источника Гарга. Анализ собранных метагеномных последовательностей позволил систематизировать и дать характеристику выявленных генов. Сравнение метагеномных последовательностей репрезентативных данных показало доминирование ферментов класса сериновых пептидаз. Ферменты, относящиеся к этому классу, ингибируются диизопропилфторфосфатом и фенилметилсульфонилфторидом, а также субстратоподобными галоидметилкетонами, такими как тозиллизинхлорметилкетон (TLCK) или тозилфенилаланинхлорметилкетон (ТРСК). Из литературных данных известно, что сериновые пептидазы обычно активны при нейтральных и щелочных значениях $\mathrm{pH}$ и имеют оптимум $\mathrm{pH}$ между 7 и 11 [6]. На основании аминокислотной последовательности, пептидазы делят на семейства и в настоящее время выделено более 20 семейств. В нашем исследовании было выявлено 7 представителей сериновых пептидаз (табл. 4). Принято считать, что эволюционное родство ферментов выражается в гомологии первичной и сходстве пространственной структур. Поэтому этим признакам придается большое значение. Известны случаи, когда сходство структуры каталитического центра не сопровождается гомологией пространственной и первичной структур. Вероятно, такое сходство является следствием конвергентной эволюции.

Метагеномный анализ позволил выявить распространение пептидаз класса металлопептидаз в изученных микробных сообществах. В классе металлопептидазы выделяют 25 семейств, обнаруженных в разных систематических группах. Металлопептидазы, как правило, синтезируются в неактивной форме и активируются в присутствии ионов металлов (магния, марганца, кобальта, цинка). Активность металлопротеиназ подавляется веществами, связывающими металлы ЭДТА, 1,10-фенантролином, версеном, цитратом, фосфамидом и др. Оптимальные значения $\mathrm{pH}$ для металлопротеиназ также лежат в диапазоне 7-9. Также известны металлопротеиназы, обладающие свойствами термостабильности [3].

Обнаружены единичные последовательности генов класса цистеиновых пептидаз в микробном сообществе Гарга. Возможно, это связано с тем, что цистеиновые пептидазы эффективны при нейтральных значениях $\mathrm{pH}$; реже зона оптимума лежит в слабокислой или слабощелочной среде ( $\mathrm{pH} 4-9)$ в зависимости от природы гидролизуемого белка [3]. У изученного нами микробного сообщества диапазон развития находится в высокотемпературной зоне и щелочной области $\mathrm{pH}$. В состав активного центра цистеиновых пептидаз входит цистеин и гистидин [7]. Цистеиновые пептидазы активируются синильной кислотой и сульфгидрильными соединениями - восстановленным глутатионом, дитиотреитолом, 2-меркаптоэтанолом и цистеином.

Таким образом, на основе анализа препаратов тотальной ДНК микробных сообществ горячих источников Байкальской рифтовой зоны методом высокопроизводительного секвенирования были получены данные о высоком разнообразии природных пептидаз в исследуемом микробном сообществе, которые обеспечи- 
вают гидролиз биополимеров на первых этапах деструкции органического вещества.

В метагеномных последовательностях были идентифицированы потенциальные пептидазы, которые могут представлять биотехнологический интерес. Их использование в разных областях промышленности, медицины, биоремедиации обусловлено несколькими факторами: снижением риска контаминации, увеличением скорости процессов и повышением общей стабильности ферментов.

Работа поддержана бюджетной темой ИОЭБ СО РАН АААA-А17-117011810034-9

\section{Литература}

1. Замана Л. В., Хахинов В. В., Данилова Э. В., Бархутова Д. Д. Гидрохимия минеральных вод // Геохимическая деятельность микроорганизмов гидротерм Байкальской рифтовой зоны. Новосибирск: Академическое изд-во «Гео». 2011. С. 62-101.

2. Obayashi Y., Ueoka N., Suzuki S. Degradation and utilization of protein derived from Pseudomonas aeruginosa by marine microbial community // J. Oceanogr. 2010. V. 6. P. 513521.

3. Oliveira A. S., Filho J. X., Sales M. P. Cysteine proteinases cystatins // Braz Arch Biol Technol. 2003. V. 46, № 1. P. 91-104.

4. Orsi W. D., Smith J. M., Liu S. and oth. Diverse, uncultivated bacteria and archaea underlying the cycling of dissolved protein in the ocean // ISME J. 2016. V. 10. P. 2158-2173.

5. Vranova V., Rejsek K., Formanek P. Proteolytic activity in soil: A review // Applied Soil Ecology. 2013. V. 70. P. 23-32.

6. Rao M. B., Tanksale A. M., Ghatge M. S., Deshpande V. V. Molecular and biotechnological aspects of microbial proteases // Microbiol. Mol. Biol. Rev. 1998. V. 62, № 3. P. 597-635.

7. Rawlings N. D. and Barrett A. J. Evolutionary families of peptidases // Biochem. J. 1993. V. 290. P. 205-218.

\section{SEARCH FOR NATURAL PEPTIDASES IN THE MICROBIAL MAT OF HOT SPRING GARGA AND THEIR VARIETY}

Lavrentieva E. V.

Candidate of Biological Sciences

Institute of General and Experimental Biology SB RAS

670047, Ulan-Ude, Sakhyanova Str., 6

Buryat State University

670000, Ulan-Ude, Smolina Str., 24A

E-mail: lena_1@mail.ru

Radnaev $V . S$.

GAUZ RK BSMP named after V. V. Angapov

Bacteriological laboratory

670000, Ulan-Ude, Trade Union, Str., 48 a

The aim of the study is to determine the natural peptidases in the microbial mat of the Garga hot spring and their diversity. The article is devoted to a comprehensive study of peptidases, which are a separate group of hydrolytic enzymes involved in the decomposition of organic matter. The scientific novelty of the work lies in the analysis of preparations of microbial communities of hot springs of the Baikal rift zone by high-performance sequencing, which 
E. В. Лаврентьева, В. С. Раднаев. Поиск природных пептидаз в микробном мате горячего источника Гарга и их разнообразие

provide hydrolysis of biopolymers at the first stages of destruction of organic matter. As a result, a metagenomic analysis was performed, which revealed the spread of metalpeptidases in the studied microbial communities. Potential peptidases that may be of biotechnological interest have been identified in metagenomic sequences.

Keywords: peptidases, microbial mat; hydrolytic enzymes; metallopeptidases; metagenomes; sequencing; Baikal rift zone. 